\title{
Corrigendum: 3D Electron Microscopy Gives a Clue: Maize Zein Bodies Bud From Central Areas of ER Sheets
}

\author{
Elsa Arcalis, Ulrike Hörmann-Dietrich, Lukas Zeh and Eva Stoger* \\ Department of Applied Genetics and Cell Biology, University of Natural Resources and Life Sciences, Vienna, Vienna, Austria
}

\section{OPEN ACCESS}

Approved by:

Frontiers Editorial Office

Frontiers Media SA, Switzerland

*Correspondence: Eva Stoger eva.stoeger@boku.ac.at

Specialty section: This article was submitted to

Plant Cell Biology,

a section of the journal

Frontiers in Plant Science

Received: 17 July 2020

Accepted: 31 July 2020

Published: 18 August 2020

Citation:

Arcalis E, Hörmann-Dietrich U, Zeh L and Stoger E (2020) Corrigendum: 3D

Electron Microscopy Gives

a Clue: Maize Zein Bodies Bud

From Central Areas of ER Sheets.

Front. Plant Sci. 11:1266.

doi: $10.3389 /$ fpls.2020.01266
Keywords: cereal endosperm, electron microscopy, endomembrane system, endoplasmic reticulum, maize, protein bodies, volume electron microscopy

\section{A Corrigendum on}

3D Electron Microscopy Gives a Clue: Maize Zein Bodies Bud From Central Areas of ER Sheets By Arcalis, E., Hormann-Dietrich, U., Zeh L., and Stoger, E. (2020). Front Plant Sci. 11:809. doi: $10.3389 /$ fpls.2020.00809

\section{MISSING FUNDING}

In the original article, we neglected to acknowledge the HRSM project NANOBILD for infrastructure support. The corrected acknowledgment statement appears below:

The authors thank Dietmar Pum (Department of Nanobiotechnology, BOKU, Vienna) for technical advice and acknowledge the HRSM project NANOBILD for infrastructure support.

The authors apologize for this error and state that this does not change the scientific conclusions of the article in any way. The original article has been updated.

Copyright () 2020 Arcalis, Hörmann-Dietrich, Zeh and Stoger. This is an open-access article distributed under the terms of the Creative Commons Attribution License (CC BY). The use, distribution or reproduction in other forums is permitted, provided the original author(s) and the copyright owner(s) are credited and that the original publication in this journal is cited, in accordance with accepted academic practice. No use, distribution or reproduction is permitted which does not comply with these terms. 